Pain: The Door to Agony and Ecstasy in Time of Covid-19 Pandemic / 1 Salesian Journal of Humanities and Social Sciences, Vol. XI, No.2 (Dec 2020) ISSN: 0976-1861 | DOI: 10.51818/SJHSS.11.2020.1-12 | Page: 1-12,

Section: Articles

\title{
Pain: The Door to Agony and Ecstasy in Time of Covid-19 Pandemic
}

George Thadathil is the Principal of Salesian College, Sonada and Siliguri. He is the author of Vision from the Margin and has edited and co-edited number of books besides contributing to a number of journals and edited volumes. He is the founder Director of Salesian Publications, Salesian Research Centre and Salesian Translation Centre.

\section{Abstract}

The paper attempts to locate pain - mental and physical - at the intersections of spiritual-philosophy and contingencies of viral agony. Through an extrapolation of dialectics of vipassana as mode of being and becoming, the paper situates pain through the exegesis of experience and the current pandemic - as an expression immanent within healing.

Keywords: Pain, vipassana, spiritual-philosophy, pandemic, being.

Pain is a human condition. Pain is experienced in different ways - mental or physical-as part of being a bodily entity. To be human is to be 'sense-driven' - as with the animals. To be human is to be 'reason-and-faith-driven' person. It justifies the classical definition of the human as a 'rational animal'. Humans are capable of inflicting pain and experience pain being inflicted upon; even more, while experiencing pain can inflict pain on others and/ or self. The ability to experience pain is intrinsic to being human, though there are medically testified persons who do not feel pain, even as there are persons who feel pain acutely more than others. Yudhijit Bhattacharjee, reporter for National Geographic elaborates this through a case study:

Norris, who lives in a Los Angeles suburb, ... [is one who has] become adept at wearing a mask of serenity to hide his pain. I never saw him wince. When his agony is especially intense, his wife of 31 years, 


\section{2 / George Thadathil}

Salesian Journal of Humanities and Social Sciences, Vol. XI, No.2 (Dec 2020)

ISSN: 0976-1861 | DOI: 10.51818/SJHSS.11.2020.1-12 | Page: 1-12,

Section: Articles

Marianne, says she can tell by a certain stillness she sees in his eyes. For three decades ever since he underwent radiation therapy, he has been experiencing acute pain, though cured of the cancer for which he undertook the treatment. He has become 'an advocate for chronic pain sufferers and started a support group. There are over 50 million people with chronic pain in US alone and millions more all over the world for varying types of causes. ${ }^{1}$

Pain, suffering or physical agony, disrupts the normal flow of life. The capacity to feel pain, though regarded as debilitating, is a gift humankind shares with the animal kingdom enabling the natural recoiling from pain-causing objects and situations. It helps avoid injury serving as an alarm system to succeed in self-preservation. Therefore, scientifically speaking:

The sentries in this system are special class of sensory neurons called nociceptors, which sit close to the spine, with their fibers extending into the skin, the lungs, the gut, and other parts of the body. They're equipped to sense different kinds of harmful stimuli: a knife's cut, the heat of molten wax, the burn of acid. When nociceptors detect any of these threats, they send electrical signals to the spinal cord, which transmits them via other neurons to the brain. Higher order neurons in the cortex - the final destination of this ascending pain pathwaytranslate this input into the perception of pain. ${ }^{2}$

The perception of pain, as narrated above and in all its range of intensity, is a neural activity coordinated by the brain. These pain receptors and nociceptors have been studied in the attempts to lessen pain. In these testing processes drugs, poisons, intoxicants and even psychedelic VR (virtual reality) has been fed to the brain to gauge their ability to control pain perception. While these are medical experiments and bio inducers, there have been spiritual attempts to conquer pain.

'Vipassana' is one such attempt to transcend pain. It emphasizes, apparently rather simplistically, the attention to pain - while being in pain - as the possible way to overcome pain. It focuses on ceding

${ }^{1}$ Yudhijit Bhattarcharjee, "A World of Pain", National Geographic, January 2020, 40. ${ }^{2}$ Ibid. 
Pain: The Door to Agony and Ecstasy in Time of Covid-19 Pandemic / 3

Salesian Journal of Humanities and Social Sciences, Vol. XI, No.2 (Dec 2020)

ISSN: 0976-1861 | DOI: 10.51818/SJHSS.11.2020.1-12 | Page: 1-12,

Section: Articles

to pain without judgmental attitude of condemning nor having undue attachment. The dispassionate observation of the flow of life, whether it is pleasant or unpleasant, painful or joyful, with equanimity creates over a period of extensive focused sitting, a door to transcend pain. Acceptance of reality as it is, here and now, without any inducements, enhancers, depressants, negators, but pure unbiased, here and now observation, opens the door. ${ }^{3}$

Vipassana as a meditation technique guides one through this observation strategy and access to reality without hindrance, without colouring and coding, without bias or ideology or faith. One might rightfully observe it as emerging from the Buddhist tradition and therefore, as invested with the worldview of the Buddhist understanding of life. Yet, as both faith and reason are fundamental categories of being, even as space and time, to be able to observe reality with sense and intellect, one cannot deny the operation of both sense and mind, reason and faith, in the very decision to observeand continue to observe irrespective of what happens, till one begins to see for oneself the truth of the reality unfolding itself. This was the project of Buddha, from the plethora of yogic practices available in his day, brought to perfection by himself in and through his own enlightenment. One could see some parallels in the Meditations of Rene Descartes (1596-1650) and David Hume (17111776), both in divergent ways, and of Immanuel Kant (1724-1804) bringing them into synthetic apriori synchronization, ${ }^{4}$ all of them starting from the experience of reality-observed and assessed for its truthfulness - with their own penetrating minds.

Doing vipassana one gets a firsthand inner experience of how pain arises and disappears - in one's own body mind complex that constitutes the self/ person. Pain whether physical or mental-arises, and falls or disappears. There is a fluctuation in the pain, its intensity, its arising and disappearing. Therefore, this movement from pain to painlessness and back to pain, could be interpreted as one way of

${ }^{3}$ Cf. Vipassana Research Institute, Igatpuri, Maharashtra: www.vri.dhamma.org.

${ }^{4}$ Cf. Steven Moctezuma, "Kant's synthetic a priori knowledge", April 24, 2018. https:/ / medium.com/@smoctezuma/kants-synthetic-a-priori-knowledge8c196dbd230f 


\section{4 / George Thadathil}

Salesian Journal of Humanities and Social Sciences, Vol. XI, No.2 (Dec 2020)

ISSN: 0976-1861 | DOI: 10.51818/SJHSS.11.2020.1-12 | Page: 1-12,

Section: Articles

transcending pain. It is there and yet it is not there- both become real experience for the one who is observing it dispassionately. Of course, can that be done? Can one be dispassionate while in pain? This is the point of acute observation, intense, clarified, pure observation that vipassana teaches - as possible.

Pain is therefore, both a bodily state and an emotional state: the body in pain, creates an emotion, and the emotion of pain makes one see and feel it in one's body as breathlessness, tension, stress, fear, timidity, sweating and specific body parts as crunching. These pains and their sources, the causes and its sense-perceptions through neurons and nociceptors have been studied by scientists. These pains and the way to cope with them have been suggested by meditators. The observation of the scientific kind brings out certain information about the source, the cause and the mode in which it is spread and felt, and can be camouflaged, or hidden, or borne by the individual.Even so, the meditators, in their observation with intent concentration, and equanimity and equidistance from the pain, also come to see its dissociation from the brain-mind that registers the pain, and allows the same pain to be transcended into bliss.

\section{Does it Help? Understanding the Observation}

At this point, presuming the truth of the scientific observation as well as the scientifically oriented meditative observation, and what it can do to oneself and through self to wider network of persons around oneself or the practicing community, we could introduce the theoretical understanding of this phenomenon-from a psychological, political as well as theological dimension. It would attempt to understand acts of withdrawal (meditative/mindfulness observation) in intense moments of engagement or attachment.

Firstly, withdrawal, has primarily a psychological dimension. It is a retrieval of something in one's consciousness, on the one hand, and allowing it to happen by closing one's attention to other external immediate requirements, on the other. In this choice itself, one could presume a wellness project, as to distance in order to keep mental calm, to view the conflictual situation, internal or external in all its 
Pain: The Door to Agony and Ecstasy in Time of Covid-19 Pandemic / 5

Salesian Journal of Humanities and Social Sciences, Vol. XI, No.2 (Dec 2020)

ISSN: 0976-1861 | DOI: 10.51818/SJHSS.11.2020.1-12 | Page: 1-12,

Section: Articles

implications, and to assess various ways of coping with it. This choice therefore of a withdrawal-as a psychological decision - is something that a person makes consciously in order to be more attentive to the problems at hand, rather than totally abandoning the cause or attempting to be dispassionate merely for one's peace of mind.

Secondly, the very same choice of withdrawal could be looked at politically, as a mode of resistance, and the quality of that resistance not always as defined by the decibel or the spread of media reach it achieves. My memories go back to visiting a meditation centre where over 120 meditators were engrossed in vipassana - a centre hidden away in the mountain reserves of Anisakan in Myanmar even as the political turmoil in the northern states continued and the unrest of under development simmered in the capital. And, of another visit wherein two dozen meditators from all walks of life in a hidden enclave in the forests of East Sikkim, even as the state was redefining itself as the most organic-food production and consumption oriented state in the country. The very attempts by the teachers of schools and colleges in this enclave in Sikkim to sit in for vipassana and experiment the ways - to indigenize education and to play a mediatory role between the eastern and western technologies of the self. What would be the ways in which these acts amidst an unsettled population be recalled as?

There are experiences that do not fight the dominant systems over identity or power. Acts of resistance shelter experiences in their depths that generate new ways of living that the dominant systems are unaware of or have not yet been able to control, those that collectively illuminate care for Life in the areas of education, health, production and care for one another. ${ }^{5}$

Thirdly, in these individuated or non-networked group'sindependent acts of resistance-in view of neutrality and approaches other than the dominant-one could see a divine anarchy. Theologically speaking this notion draws inspiration

\footnotetext{
${ }^{5}$ Juan Carlos La Puente Tapia, “Acts of Resistance: Messianic Force of Divine Anarchy", in Carlos Mendoza-Alvarez and Thierry-Marie Courau (eds) Concilium: Decolonial Theology: Violence, Resistance and Spiritualities, 2020/1 International Journal of Theology, 92.
} 


\section{6 / George Thadathil}

Salesian Journal of Humanities and Social Sciences, Vol. XI, No.2 (Dec 2020)

ISSN: 0976-1861 | DOI: 10.51818/SJHSS.11.2020.1-12 | Page: 1-12,

Section: Articles

from the Syro-Malankara ${ }^{6}$ liturgical veneration of an empty cave as a theophany and also the Jewish mystical texts that refer to abandoning the illusion of being separate from something else, as the opening to the life that has no beginning and no end. It is also taking grips over an insight provided by Raimondo Panikkar that, 'the only possible mediation' for one who opens to the divine mystery was nothing less than mere 'naked existence'. In his words: 'We have to be 'nothing' to experience in ourselves the Creator of nothingness."

As an expert in bringing together different mystical traditions, he is authoritative when he affirms: 'this becoming aware, that in ourselves,we are without beginning and without end is precisely the experience of divinity. ${ }^{8}$ This merging ofthe nothingness and the emptiness of the mind and the awareness to the here and now, with the neutrality of the absolute openness of the moment is what in Meister Eckhart's (1260-1328) experience as narrated by his disciple Juan Taulero in the fourteenth century, claims: "Let the abyss of the divine darkness, known only by itself and unknown by all things, enlighten you. This blessed abyss, unknown and nameless, will be more beloved and will attract souls more than all that the saints in blessedness may know of divine being." 9 Of course on an aside, this quote reminds me of what I heard decades ago, being with an international group of young people, in Taize, France: "I was an atheist, until I discovered, I am God." 10

Eckhart himself refers to this abyss as that place-wherein the superabundant birth of divine love as pure encounter, pure relatedness as happening - in the words: "You must plunge you 'being you' in his 'being him' so that 'yours' and 'his' becomes a 'my-being' through mutual possession in love." ${ }^{11}$ It is the prescience

${ }^{6}$ See, https:/ / catholicsindia.in/the-syro-malankara-church.

${ }^{7}$ Raimon Panikkar, The Experience of God, icons of the Mystery, (Minneapolis: Fortress Press, 2006), 154.

${ }^{8}$ Ibid, 163.

${ }^{9}$ Quoted from Juan Carlos La Puente, 96.

${ }^{10}$ George Thadathil, Unpublished Diary Notes, July 1994.

${ }^{11}$ Ibid. 
Pain: The Door to Agony and Ecstasy in Time of Covid-19 Pandemic / 7

Salesian Journal of Humanities and Social Sciences, Vol. XI, No.2 (Dec 2020)

ISSN: 0976-1861 | DOI: 10.51818/SJHSS.11.2020.1-12 | Page: 1-12,

Section: Articles

of the sage at play and the meditator is on the way to the immersion into that insightful living. Therefore, as Raimondo Panikkar reminds: 'the sage is the person who has the heart of the whole people' and Meister Eckhart, repeating a popular belief say that 'anyone who knows themselves, knows all creatures' (specifically in his treatise onTheNobleman). This chain uniting everything with everything else makes us one with nature through contemplation, prayer, glory, but also through our participation in the pains of creation, whether pains of birth or despair. ${ }^{12}$

\section{Painfully Neutral or Neutrality in Pain?}

In doing Vipassana, the ability to be 'neutral' in observing - the happening and response to it - canbe identified as the secret that unveils the unknown about the nature of pain. The ability to be equipoised: in attending to whatever arises and passes in the here and now! This training begins with simple observation of breath as it is-uncontrolled, normal, natural breathing-theundeniable sign of life that lurks in the body and links the body with the mind/soul/spirit that hovers in and around the body, in it and everywhere, and over and above it as it were. The breath becomes the vehicle and object of observation by the mind that is kept alive by the same breath. Dispassionately observing it for hours on end, being true to the factuality of the here and now - with no intoxicants, external inducers - allows for the natural bare true reality to expose itself as containing the access point-door-to something transreal, something extra ordinary. The access to an altered state of consciousness happens, even as you are aware of the transition - of being here and of being not here, or being over-and-above being here and now. It is an experience that has been recorded and verified experimentally by the psychologists - of the explorations into breath-work, psychedelics and drug induced meditations and healing experiences. ${ }^{13}$ These transitions into the altered state

\footnotetext{
${ }^{12}$ Raimon Panikkar, op cit., 135.

${ }^{13}$ Cf. Stanislav Grof, The Transpersonal Vision: The Healing Potential of Non-Ordinary States of Consciousness, (California: Sounds True, 2006); Beyond the Brain: Birth death, and Transcendence in Psychotherapy (New York: SUNY Press, 1985).
} 


\section{8 / George Thadathil}

Salesian Journal of Humanities and Social Sciences, Vol. XI, No.2 (Dec 2020)

ISSN: 0976-1861 | DOI: 10.51818/SJHSS.11.2020.1-12 | Page: 1-12,

Section: Articles

of consciousness that happens simply through the normal natural breathing observed through the dispassionate neutral, equipoised observation strategies of vipassana, takes one to the altered state and does many things to a person. ${ }^{14}$

The ability to cope with pain is one such accomplishment or giftedness of being a vipassana meditator. It always begins with and falls back to the natural realistic observation of the 'pleasant and the unpleasant' in the here and now; pain in varying degrees happens to be variants of this pleasant-unpleasant spectrum that presents itself to oneself at any given moment: facing it enables to deal with it, even as drugging it helps, or VR inducement helps. In principle and as from experience, one cannot also rule out the very opposite happening from unattended pain - whether self-induced or other induced. The long hours of sitting and the willingness to submit to the instructor and the guidance-that come from a tradition of experienced meditators - can take one to the intended goal of ecstasy, transcendence of pain, and access to non-ordinary states of consciousness and healing.

The agony of the meditator also means accounting for the impact-the process of breathing with intense concentration has on the breather, the meditator. One observation has been that the outcome is a shallow breathing phase into which the brain enters after a while. As a result, there could also be the opposite outcome. Someone not succeeding to find the door and make the entry into the 'transcendence of pain,' rather succumbs and the mind-body integrity breaks down and one is left with access to other orders of pain, or discordance which does not add up to 'normal living' as judged from the majoritarian perspective of the 'normal'. Whether this happens only to those who have had a history, or a hereditary reason to be susceptible again needs verification. ${ }^{15}$ The impact such phases of prolonged sitting with shallow breathing, and its resultant

${ }^{14}$ S. N. Goenka, The Discourse Summaries, (Bombay: Vipashayan Vishodhan Vinyas, 1989).

${ }^{15}$ https:// www.mindandlife.org/insights/ pain-relief-without-opioids/ 
Pain: The Door to Agony and Ecstasy in Time of Covid-19 Pandemic / 9

Salesian Journal of Humanities and Social Sciences, Vol. XI, No.2 (Dec 2020)

ISSN: 0976-1861 | DOI: 10.51818/SJHSS.11.2020.1-12 | Page: 1-12,

Section: Articles

low intake of oxygen into the brain system has also been mapped. The researches of the Mind and Life Institute and the Rhode Island University on the negative impact of prolonged meditation on the practitioners stand as testimony. ${ }^{16}$

The agony and ecstasy component, the shifting experiences of the pleasant and unpleasant again leaves room for a twin interpretation: one, acknowledging the truthfulness of life as an experience of a mixed bag of the pleasant and the unpleasant, joy and sorrow, pain and pleasure; and the other, an acknowledgement of the fact that this neutral approach to life and its experiences is not everyone's cup of tea, and there are individuals who cave in and are susceptible to be influenced by one or the other to an extent of losing the balance of life, making the experience a detrimental one for the life thereafter, calling for other interventions of the medical or psychiatric kind to alleviate the situation.

The practitioner then has a choice: either to continue with the vipassana mode of dispassionate observation of one's life trajectory, its ups and downs, and use this as coping strategy; or, to return to conventional medication, psychiatry or counseling to cope with the life trajectory. The source of the pain could be the direct engagement with the external world of people and events, action and its repercussions, best exemplified in the emotion of anger and all sorts of irritants that dog the day of an individual; or, it could be the fears that lurk in the subconscious of one's self, ever fretful of an unseen, unexpected cause for anxiety; fear, trepidation, danger all round, best represented in the dreams that wake you to fear something uncanny, untoward that is lurking behind the corner; or, there are the hidden residues of the suppressed and hitherto unacknowledged aspects of the hurts of the past years and lives ever threatening to surface as real nightmares drowning one in the sorrow of the past revisited.Said otherwise, hidden worries and anxieties surfacing from the inner depth that one never thought were there; the unconscious letting loose its floodgates as it were.

\footnotetext{
${ }^{16}$ https:/ / www.mindandlife.org/insights/meditation-for-mental-health-howdoes-mindfulness-compare-to-other-treatments /
} 


\section{0 / George Thadathil}

Salesian Journal of Humanities and Social Sciences, Vol. XI, No.2 (Dec 2020)

ISSN: 0976-1861 | DOI: 10.51818/SJHSS.11.2020.1-12 | Page: 1-12,

Section: Articles

Harnessing these fears, angers and the sum of pain that (some call as the pain-body $)^{17}$ and dealing with them is what the vipassana mode of handling pain is about. Allow it to surface, let the turbulence created on the calm surface of the quiet lake of a peaceful mind, be dealt by the keenly observant perceptive mind like a laser that can burn away those pains in the equanimous awareness of the moment and let the inner depths be clarified and the muddled waters cleared, bringing the mind back to its peaceful rest. It enables the mind to constantly expand and hold whatever it is that surfaces and enables it to continue despite the storms raging round with the inner quiet of an observer of passions and violence.

The way to integrity and wholeness, to wellbeing and happiness of the kind that does not shy away from pain is what vipassana offers. It is the ancient mode of VR to cope with pain without the drugs and anesthetics.

\section{The internalization of Pain: Duhkha as Suffering in Covid Times}

Is there a collective pain? Does mob violence erupt as a result of collective repressed anger seeking expression? Fear seeking mitigation? Is pain healing itself like the festering wound being healed through the emission of puss? Life is dukkha/suffering and there is a way out of suffering - is it to not-suffer or a way out through suffering? Is pain a door of entry into the paradise (land/ mental space) of non-suffering-as is experientially known by the self? Does one suffer, and endure pain only for oneself or for another? Does one inflict pain on self and on another through one's actions - one's words (written, spoken, thought)? ${ }^{18}$

${ }^{17}$ Eckhart Tolle, The Power of Now: A Guide to Spiritual Enlightenment, (Vancouver: New World Library, 1999). https:/ / www.newworldlibrary.com/Blog/tabid/767/ articleType / ArticleView / articleId/438/DISSOLVING-THE-PAIN-BODY-Anexcerpt-from-THE-POWER-OF-NOW-by-Eckhart-Tolle.aspx\#.X7ClqcgzbIV

18 [I can recall the experience of the impact of reading one's pain/suffering on one's body, in one's mind the possession of the spirit of the words and the way it wounds in narrating the words unveiling the pain suffered - just on reading it] The distant is not in the now - for it takes light years to be there where the stars are shining right now (as being there). The Now is only Here. So, every now is a here and now. 
The internalization of pain happens when the physical pain leaves a mark on mental distress as against bringing sustenance through the ability to bear it. The mental spiritual agony of not being able to do anything to alleviate the pain of others - individuals or a collective - and instead leaves physical traces or scars, the stigmata, on the body of the sufferer:

Pain, it turns out, is a complex, subjective phenomenon that is shaped by the particular brain that's experiencing it. How pain signals are ultimately translated into painful sensations can be influenced by a person's emotional state. The context in which the pain is being perceived also can alter how it feels, as evidenced by the pleasantness of the aches that follow a strenuous workout or the desire for a second helping of a spicy dish despite the punishing sting it delivers to the tongue. ${ }^{19}$

However subjective a phenomenon is, an objective materiality is ingrained as well to it, as he goes on to narrate in the same article with which we began with:

Upon registering the pain, the brain attempts to counteract it. Neural networks in the brain send electrical signals down the spinal cord along what's known as the descending pain pathway, triggering the release of endorphins and other natural opioids. These biochemicals inhibit ascending pain signals, effectively reducing the amount of pain perceived. ${ }^{20}$

These are the outcome of the research done on how pain signals are communicated from sensory nerves to the brain and how the brain perceives the sensation of pain. The lasting of the pain for more than three months after the injury, considered chronic pain, and pain as disease have from a medical point of view helped overcome earlier bias against patients who complained of pain without physical visible cause. Are they, then the saints and martyrs of a modern awareness and/or victims of nature's vagaries, impacting

\footnotetext{
${ }^{19}$ Yudhijit, 41.

${ }^{20}$ Yudhijit, 40.
} 


\section{2 / George Thadathil}

Salesian Journal of Humanities and Social Sciences, Vol. XI, No.2 (Dec 2020) ISSN: 0976-1861 | DOI: 10.51818/SJHSS.11.2020.1-12 | Page: 1-12,

Section: Articles

itself on individuals just as tsunamisand pandemics do on a human collective upon the earth? 